\title{
ENDOSCOPIC TREATMENT OF VESICOURETERAL REFLUX IN THE PREVIOUSLY REIMPLANTED URETER: TECHNICAL ASPECTS AND RESULTS
}

\author{
Nicola Capozza, Simona Nappo and Paolo Caione.
}

Department of Pediatric Urology. Bambino Gesù. Children's Hospital. Rome. Italy.

\begin{abstract}
Summary.- OBJECTIVES: To assess the feasibility and results of the endoscopic treatment of vesicoureteral reflux (VUR) after a failed ureteral reimplantation.

METHODS: From January 1996 to October 2006, 28 patients underwent endoscopic treatment for VUR grade $/ 1$ to $\mathrm{V}$ persisting after open ureteral reimplantation. VUR was bilateral in 11 patients, for a total of 39 ureteral units (UU) treated. The endoscopic treatment was performed 1 to 7 years after surgery laverage 2.5 years). Dextranomer/Hyaluronic acid Copolymer (Dx/HA) was used as injectable material. The amount of injected material ranged from 0.5 to $2.8 \mathrm{ml}$ laverage: 1.2 $\mathrm{ml}$. Some technical refinements were required to increase the
\end{abstract}

success of the procedures. Patients were followed up from 2.5 to 17 years. Voiding cystourethrogram (VCUG) was performed at 6 months and MAG3 renal scan with voiding phase at 24 months. Results were compared with the outcome of the endoscopic treatment in patients treated by the same surgeons for primary VUR, matched for grade (control group).

RESULTS: All treatments were performed as one-day procedure. No complications were observed. Success was achieved in 22/28 patients (78.5\%) and in 30/39 UU (76.9\%) after failed ureteral reimplantation. No significant difference in success rate was found from the control group ( $p=n s$ ).

CONCLUSIONS: Endoscopic treatment of VUR after a failed reimplantion can be a challenging procedure, for a skilled endoscopists. Nonetheless it can achieve successful results in a high percentage of patients with minimal morbidity and a minimal invasiveness; it should thus be recommended for these patients.

Keywords: Vesicoureteral reflux. Ureteral reimplantation. Endoscopic treatment. Dextranomer/hyaluronic acid copolymer.

Resumen.- OBJETIVO: Evaluar la viabilidad y resultados del tratamiento endoscópico del reflujo vesicoureteral (RVU) después del fracaso del reimplante ureteral.

MÉTODOS: Entre enero de 1996 y octubre del 2006, 28 pacientes fueron sometidos a tratamiento endoscópico del RVU persistente grados II a V después de reimplante ureteral. El RVU era bilateral en 11 pacientes, con un total de 39 uréteres tratados. El tratamiento endoscópico se realizó entre 1 y 7 años después de la cirugía (media 2,5 años). Como material inyectable se utilizó copolímero de ácido hialurónico/dextranomero. La cantidad de material inyectado varió entre 0,5 y 2,8 $\mathrm{ml}$ (media 1,2 ml). Fue necesaria alguna finura técnica para aumentar el éxito de los procedimientos. Los pacientes fueron seguidos entre 2,5 y 17 años. Se realizó cistouretrogra- 
fía miccional seriada (CUMS) a los seis meses y gammagrafía renal MAG3 con fase miccional a los 24 meses. Los resultados se compararon con los de un grupo control de tratamiento endoscópico en pacientes con RVU primario tratados por los mismos cirujanos, emparejados según el grado.

RESULTADOS: Todos los tratamientos fueron realizados de forma ambulatoria. No se observaron complicaciones. Se obtuvo el éxito en $22 / 28$ pacientes (78.5\%) y en $30 / 39$ uréteres (76. 9\%) después de un reimplante fallido. No hubo diferencias significativas en las tasas de éxitos comparando con el grupo control ( $p=n s$ ).

CONCLUSIONES: El tratamiento endoscópico del RVU después del fracaso de un reimplante puede ser un desafío para un endoscopista experto. Sin embargo puede conseguir resultados exitosos en un alto porcentaje de pacientes con mínima morbilidad en pasividad. Por tanto, debería recomendarse en estos pacientes.

Palabras clave: Tratamiento endoscópico. Copolímero de ácido hialurónico/dextranomero.

\section{INTRODUCTION}

In the past twenty years endoscopic treatment has become an effective alternative to either long term prophylaxis or open surgery, and has dramatically changed the management of VUR. Different injectable materials have been used along the years. These materials differ in terms of viscoelastic properties, antigenicity, biodegradability, long term migration, local immune reaction and stability at the implant site. Destranomer/Hyaluronic acid copolymer (Dx/HA) seems to have some of the properties of the ideal bulking material, since it is easy to inject, has no antigenic properties, is biocompatible, does not migrate to distant organs and is stable at the long term at the injection site (1).

With the improvements of the injectable materials, and the increasing skillfulness of paediatric urologists, the indications for endoscopic treatment of VUR have become wider. Initially regarded as an alternative to long term prophylaxis in mild grade VUR, it is nowadays performed also in grade IV and V VUR, which were traditionally treated with open surgery (2). Indeed, our group has suggested that endoscopic treatment should be regarded as the first line therapy in children with VUR (3).

Particular anatomical or functional situations, that used to be considered as "contraindication" to endoscopic treatment, no longer are. VUR in duplex kidney can be easily treated endoscopically, with results comparable (personal unpublished data) or slightly lower $(4,5)$ than primary VUR in single district. Even VUR in patients with previously resected posterior urethral valves, and in neu- rogenic bladders can be cured endoscopically. In these patients, adequate management of the co-existent bladder dysfunction is mandatory to achieve satisfactory results, since we demonstrated that bladder dysfunction in "primary" VUR may significantly affect the success of the treatment (6).

VUR appearing or persisting after open vesicoureteral reimplantation represents a disappointing problem both for the paediatric urologists and families, as spontaneous resolution is not frequent and repeated open surgery may represent a challenging procedure. We reviewed our experience in endoscopic treatment of VUR in these particular cases, in order to assess the feasibility and results of endoscopy in these patients, and compare them to the outcomes in primary VUR.

\section{PATIENTS AND METHODS}

From January 1996 to October 2006, 28 children (21 males, 7 females) aged 28 months to 16 years, were treated endoscopically at our Department for VUR appearing or persisting after ureteral reimplantation. VUR was of grade II to $V$ and was bilateral in 11 patients, for a total of 39 ureteral units (UU). VUR grading is shown in Table I. The underlying pathology requiring initial ureteral reimplantation was obstructed megaureter (15 UU), high grade VUR (22 UU), or VUR associated with ureterocele in duplex kidney (2UU). Open reimplantation was performed according to the following techniques: Hamed-Cohen (31 UU), Glenn-Anderson (2 UU), Politano-Leadbetter (4 UU), Gil-Vernet (2 UU). Tailoring of the dilated ureter was also performed in 30 UU according to Hendren's technique (18 $\mathrm{UU}$ ) or Kalicinsky's technique (12). In three patients (5 UU) open reimplantation was a redo procedure after previous surgery performed elsewhere. Age at open surgery was from 8 months to 9 years.

Endoscopic treatment of persisting VUR was performed 1 to 7 years after open surgery laverage 2.5

\section{TABLE I. VUR AFTER FAILED REIMPLANTATION, ACCORDING TO GRADE.}

\begin{tabular}{|c|c|}
\hline VUR GRADE & URETERAL UNITS \\
\hline$I I$ & 6 \\
\hline$I I I$ & 16 \\
\hline IV & 11 \\
\hline$V$ & 6 \\
\hline
\end{tabular}


years). Destranomer/Hyaluronic Acid Copolymer (Dx/HA) (Deflux®, Q-Med, Uppsala, Sweden) was used in all patients as injectable material.

The injection technique was similar to that described by Puri and O'Donnell for polytetrafluoroethylene injection (7), with some peculiar adjustments. The instrument used in most cases was a $10 \mathrm{Fr}$ cystoscope with straight operative channel, and an oblique optic lens; in older children a $14 \mathrm{Fr}$ cystoscope was used. After identifying the reimplanted orifice, a ureteral catheter was inserted in the ureteral orifice before the injection. In cases of previous transtrigonal ureteral reimplantation, gentle traction on the catheter towards the medial line helped in medializing the reimplanted orifice, in order to have it frontal, and facilitate the injection. The material was injected through a metallic semirigid $3 \mathrm{Fr}$ cannula, with a 22 gauge needle, just underneath the reimplanted ureteral orifice. In case of unsatisfactory bulking, the injection was also performed along the cross-trigonal ureteral tunnel. The amount of material injected was of 0.5 to $2.8 \mathrm{ml}$ (average $1.2 \mathrm{ml}$ ).

Follow-up was 6 months to 11 years. In all patients urinary ultrasound was performed at 1 month, VCUG at 6 months, and a MAG 3 scan with voiding phase at 24 months. In case of persisting VUR patients underwent a second injection. After VUR cure, periodical urinalysis and urinary ultrasound were performed.

Results were compared with the outcomes of the endoscopic treatment in a group of 56 pts (88 UU) treated during the same period by the same surgeons for primary VUR, matched for grade. Patients in the control group were chosen as follows: for each patient treated for VUR in a reimplanted ureter, the closest previous and following patient treated for a primary grade-matched VUR were chosen as controls. In bilateral VUR, grade matching was done with the VUR of higher grade. For statistical analysis, Fisher exact test was adopted, considering $p<0.05$ as significant.

\section{RESULTS}

All the patients were discharged within 24 hours. Except for mild transient dysuria, postoperative period was uneventful. Urinary ultrasound at 1 month showed no sign of obstruction due to the injected material.

Nine patients required two endoscopic treatments. The overall results after 1 or 2 treatments are shown in table 2. VUR was cured in $22 / 28$ patients $(78.5 \%)$, and in $30 / 39$ UU (76.9\%). Three patients with III and IV grade VUR showed a significant reduction of the pieloureteral dilatation and the downgrading of VUR to grade II: they discontinued antiobiotic prophylaxis, and are free of infection at follow-up. One male patient with persisting bilateral $V$ grade VUR underwent a redo open procedure. In two patients with persistent grade IV-V VUR, further follow-up showed the presence of occult spina bifida, requiring bladder rehabilitation in one case and bladder augmentation in the other case.

In the control group, $45 / 56$ patients $(80.3 \%)$ and $72 / 88$ UU (80.8\%) were cured after 1 or 2 endoscopic injections. The distribution according to VUR grade is shown in table 3 . The results were not statistically different between the two groups of patients $(p=n s)$.

\section{DISCUSSION}

Several open surgery techniques provide safe and effective treatment for high grade VUR or obstructive megaureter. Standard extravesical procedures, such as Lich-Gregoir technique, or intravesical procedures, such as Leadbetter-Politano or Hamed-Cohen procedures, have achieved success rates as high as $95-98 \%$ (8-10). In very dilated systems, tailoring the ureter, with longitudinal resection, or folding the excess ureteral wall, can provide better chances of success. Nonetheless, open surgery procedures are

TABLE II. RESULTS OF ENDOSCOPIC TREATMENT ACCORDING TO VUR GRADE.

\begin{tabular}{|c|c|c|c|c|}
\hline VUR GRADE & TREATED UU & CURED VUR & REDUCED VUR & PERSISTING VUR \\
\hline$I I$ & 6 & 6 & - & - \\
\hline$I I$ & 16 & 14 & 2 & 2 \\
\hline$I V$ & 11 & 8 & 1 & 2 \\
\hline$V$ & 6 & 2 & 2 & 4 \\
\hline TOT & 39 & $30(76.9 \%)$ & 5 & 2 \\
\hline
\end{tabular}


not totally free from complications, even in the best hands. Obstruction after ureteral reimplantation has been reported to occur in 0.3 to $9.1 \%$ of cases, in which reoperation was required $(10,11)$. Viceversa, failure of open surgery with persistent VUR has been reported in the International Reflux Study Committee to occur in 0 to $8 \%$ of all cases, and in up to $19 \%$ of grade V VUR $(9,12)$. Of the different techniques of ureteroneocystostomy in use, none seems to be decisively better than another $(9,10)$.

VUR persisting after ureteroneocystostomy represents a disappointing problem for parents, children and not last for surgeons as far as management is concerned. The chance of a spontaneous cure rate led some Authors (9) to a conservative approach, with long term antibiotic prophylaxis. A low grade VUR can spontaneously disappear at 1 year follow-up and is generally due to transient edema of the neo uretero-vesical junction (13). However, in 30\% of children with VUR 1 year after ureteral reimplantation, VUR was still present at 5 year of follow-up, thus showing therefore a low tendency towards spontaneous resolution (9).

Persistent VUR may be due to technical faults, such as a large atonic ureter, or a short submucosal tunnel. A length/width ratio of $5 / 1$ is indeed recommended to assure an antireflux mechanism (14). In our experience, in 24/39 UU $(61.5 \%)$ the tunnel of the reimplanted ureter was described as "short" or "retracted" at endoscopy. Alternatively, the presence of voiding dysfunction such as a poorly compliant bladder or inadequate emptying can greatly affect the results of open surgery. A failure rate up to $30 \%$ has been reported by Koff in children with detrusor overactivity or detrusor/sphincter dysfunction (15). Two of our patients with persistent VUR were indeed found to have a previo-

TABLE III. RESULTS OF ENDOSCOPIC TREATMENT IN PRIMARY VUR (CONTROL GROUP).

\begin{tabular}{|c|c|c|}
\hline VUR GRADE & TREATED UU & CURED VUR \\
\hline$I$ & 4 & 4 \\
\hline II & 18 & 16 \\
\hline III & 35 & 31 \\
\hline IV & 24 & 18 \\
\hline V & 8 & $32(80.9 \%)$ \\
\hline TOT & 89 & \\
\hline
\end{tabular}

usly undetected occult spinal disraphism, which required bladder urotherapy and, in one case, bladder augmentation.

In the patients with failed reimplantation, recurrent urinary tract infection and low parental compliance for long term prophylaxis, require an effective solution. Redo surgery can be a tedious and technically demanding procedure, often requiring additional procedures, such as Boari flaps or bladder psoas-hitch. The risk of ureteral devascularization is not negligible and success rate is about $80 \%(16)$.

Our experience with endoscopic treatment clearly shows that the injection of a bulking material can be a simple and highly successful procedure in these patients, avoiding the risks of a redo open surgery. A similar experience was reported by Kumar and Puri (17), who treated with Polytetrafluoroethylene 31 patients presenting with a failed reimplantation, and obtained a success rate of $68 \%$ after 1 injection and $95 \%$ after 3 injections. Gaschignard treated endoscopically 12 children with a failed Cohen procedure, with a cure rate of $75 \%$ (18) and Perez-Brayfield had a cure rate of $88 \%$ out of 17 children treated with $\mathrm{Dx} / \mathrm{HA}$ injection (5). In these patients some technical refinements may increase the success of this procedure. Especially in cases of transtrigonal ureteral reimpantation, we recommend to medialize the ureteral orifice by a gentle traction on 3 or 4 Fr indwelling ureteral catheter, in order to inject the material just at the orifice.

A second technical point is to inject additional bulking material underneath the transverse transtrigonal tunnel. In our hands the endoscopic injection was indeed a 10-15 minute procedure, had no complications and required short hospital stay. Success rate was satisfactory: $75.9 \%$ of UU were cured. Indeed the cure rate was not significantly different from what observed during the same period in a group of children with primary VUR, matched for grade (Table III). The amount of material injected was slightly higher in postreimplant VUR than for primary VUR (1.2 $\mathrm{ml}$ vs $0.8, \mathrm{p}=\mathrm{ns})$. Children with VUR persisting to a lower degree discontinued antibiotic prophylaxis, without febrile urinary infections. At 24-month follow-up results were stable. At long term follow-up only 2 patients out of 28 required a redo open surgical procedure $(1$ of the two had bladder augmentation for neurogenic bladder due to occult spina bifida).

\section{CONCLUSIONS}

Endoscopic treatment of VUR after a failed reimplantion is a feasible, minimally invasive procedure. The short hospital stay, the absence of complications, the safety of the currently available injectable materials, and the high rate of success lead us to strongly recommend the subeteric injection of a bulking material as a first line treatment, even in these particular patients. We believe endoscopic treatment should always be attempted in these complex cases of VUR, before committing patients to more difficult open procedures, which are not devoid of complications. 


\section{REFERENCES AND RECOMENDED READINGS (*of special interest, ${ }^{* *}$ of outstanding interest)}

1. LACKGREN, G.; WAHLIN, N.; SKOLDENBERG, E. y cols.: "Long term follow up of children treated with destranomer/hyaluronic acid copolymer for vesicoureteral reflux". J. Urol., 166: 1887, 2001.

2. CHERTIN, B.; DE CALUWE, D.; PURI, P.: "Endoscopic treatment of primary grades IV and V vesicoureteral reflux in children with subureteral injection of polytetrafluoroethylene". J. Urol., 169: 1847, 2003.

3. CAPOZZA, N.; LAIS, A.; NAPPO, S. y cols.: "The role of endoscopic treatment of vesicoureteral reflux: A 17 year experience". J. Urol., 172: 1626, 2004.

4. LACKGREN, G.; WAHLIN, N.; SKOLDENERG, E. y cols.: "Endoscopic treatment of vesicoureteral reflux with dextranomer/hyaluronic acid copolymer is effective in either double ureters or a small kidney”. J. Urol., 170: 1551, 2003.

*5. PEREZ-BRAYFIELD, M.; KIRSH, A.J.; HENSLE, T.W. y cols.: Endoscopic treatment with destranomer/ hyaluronic acid for complex cases of vesicoureteral reflux". J. Urol., 172: 1614, 2004.

*6. CAPOZZA, N.; LAIS, A.; MATARAZZO, E. y cols.: "Influence of voiding dysfunction on the outcome of endoscopic treatment for vesicoureteral reflux". J. Urol., 168: 1695, 2002.

*7. O'DONNELL, B.; PURI, P.: "Treatment of vesicoureteric reflux by endoscopic injection of Teflon". Br. Med. J., 289: 7, 1984.

8. KENNELLY, M.J.; BLOOM, D.A.; RITCHEY, M.L. y cols.: "Outcome analysis of bilateral Cohen cross-trigonal ureteroneocystostomy”. Urology, 46: 393, 1995.
9. HJALMAS, K.; LOHR, G.; TAMMINEN-MOBIUS, T. y cols.: "Surgical results in the international reflux study in children (Europe)". J. Urol., 148: 1657, 1992.

10. WEISS, R.; DUCKETT, J.; SPITZER, A.: "Results of a randomized clinical trial of medical versus surgical management of infants and children with grade III and IV primary vesicoureteral reflux (United States)". J. Urol., 148: 1667, 1992.

**11. ELDER, J.S.; DIAZ, M.; CALDAMONE, A.A. y cols.: "Endoscopic therapy for vesicoureteral reflux: a metaanalysis. I. Reflux resolution and urinary tract infection". J. Urol., 175: 716, 2006.

**12. DUCKETT, J.; DIXON WALKER, R.; WEISS, R.: "Surgical results: International reflux study in childrenUnited States Branch”. J. Urol., 148: 1674, 1992.

13. GIBBONS, M.; GONZALES, E. Jr.: "Complications of antireflux surgery”. Urol. Clin. North Am., 10: 489, 1983.

14. STEPHENS, F.D.; LENEGHAN, D.: "Anatomical basis and dynamics of vesicoureteral reflux". J. Urol., 87: 669, 1962.

*15. KOFF, S.A.: "Relationship between dysfunctional voiding and reflux". J. Urol., 148: 1703, 1992.

*16. GEARHART, J.P.; LEONARD, M.P.: "Reoperative ureteral reimplantation: Strategies for management". J. Ped. Surg., 26: 58, 1991.

*17. KUMAR, R.; PURI, P.: "Endoscopic correction of vesicoureteric reflux in failed reimplanted ureters". Eur. Urol., 33: 98, 1998.

18. GASCHIGNARD, N.; PLATTER, V.; BOULLANGER, P. y cols.: "Endoscopic treatment of residual vesico-ureteral reflux after reimplantation in children: Twelve cases". Prog. Urol., 7: 618, 1997. 